\title{
Kananmunan kuoren kestävyyden parantaminen
}

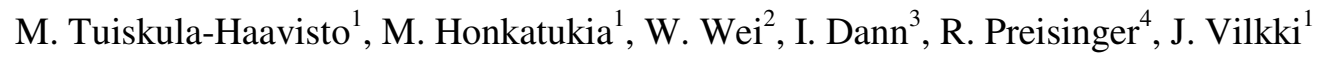 \\ ${ }^{1}$ Animal Genomics, Biotechnology and Food Research, MTT Agrifood Research Finland, 31600 Jokio- \\ inen, Finland \\ ${ }^{2}$ Human Genetics Unit, Medical Research Council, Western General Hospital, Crewe Road, Edinburg \\ EH4 2XU, Scotland UK \\ ${ }^{3}$ The Roslin Institute and R(D)SVS, University of Edinburgh Roslin BioCentre, Midlothian \\ EH25 9PS, Scotland UK \\ ${ }^{4}$ Lohmann Tierzucht GmbH, P.O.Box 460 D- 27454 Cuxhaven
}

\section{Tiivstelmä}

SABRE-hankkeessa tutkimuspopulaatio koostuu Lohmann Tierzucht jalostusyhtiön kahden eri ruskean linjan risteytyksestä. Noin 2000 kanasta koostuva tutkimussukupolvi oli koko tuotantokauden (elinviikot 18 - 60) tuotannontarkkailussa. Munan laatua tutkittiin Canadian Egg Shell Tester laitteella, jolla saadaan selville munankuoren jousto ja kesto. Kuorenpaino mitattiin kerran 42 viikon iässä. Vuoden 2007 loppuun mennessä tehtiin alustava ominaisuuksiin vaikuttavien kromosomialueiden kartoitus tutkimuspopulaation 668 eläimestä.

Kaikista tutkimusukupolven eläimistä ja niiden vanhemmista ja isovanhemmista otettiin verinäyte, josta eristettiin DNA. DNA- merkkeinä käytettiin selkeästi tunnistettavia DNA-jaksoja, joiden paikka kromosomissa on tarkalleen jo määritetty. Näillä merkeillä ei itse ole vaikutusta tutkittavaan ominaisuuteen. Mitä lähempänä tiettyä geenimerkkiä ominaisuuteen vaikuttava geeni sijaitsee, sitä useammin geenimerkki ja geeni periytyvät yhdessä. Tätä tietoa käytetään hyväksi kun tilastotieteen menetelmillä analysoidaan minkä geenimerkin läheisyydessä tutkittavaan ominaisuuteen vaikuttava geeni sijaitsee.

Tutkimus käsitti 160 DNA-merkkiä 26 kromosomissa. Tutkimuksessa testattiin erilaisia tilastollisia analyysimalleja sekä geenien yhdysvaikutuksia kuoren laatuominaisuuksiin yhteistyössä Roslin Instituutin kanssa. Kanan genomista löytyi useita kuoren laatuun vaikuttavia kromosomialueita, joista lupaavimmat valittiin jatkotutkimuksiin. Kuoren kestävyyteen ja joustoon sekä alku- että loppumunintakaudella vaikuttavia alueita löytyi kromosomeista 2, 3, 6, 14, ja Z. Jatkokartoituksessa keskitytään näiden alueiden tarkempaan analysointiin koko 2000 eläimen populaatiossa käyttäen lähekkäin sijaitsevia DNA-merkkejä. MTT:ssä keskitytään kromosomeissa 14 ja Z oleviin alueisiin.

Avainsanat: siipikarja, kananmunan laatu, QTL-kartoitus 


\section{Johdanto}

Kuorenkestävyyden parantaminen kiinnostaa sekä jalostajaa, tuottajaa että kuluttajaa, sillä kestävä, ehjä kuori on tärkeä kaikissa munantuotannon vaiheissa (keruu, pakkaus, kuljetus), ja lisäksi se on oleellinen suoja ulkoisia taudinaiheuttajia vastaan (tuotteen turvallisuus). SABRE-hankkeen työpaketin 7:n lähtökohta on kananmunan turvallisuus elintarvikkeena. Tutkimusta on perusteltu seuraavasti:

EU:ssa tuotetaan ja syödään vuosittain noin 5 miljoonaa tonnia kananmunia. Kananmuna sisältää korkealaatuista proteiinia ja se hyväksytään elintarvikkeeksi laajasti eri kulttuureissa. Toisaalta kananmuna on myös otollinen kasvualusta vaarallisille taudinaiheuttajille kuten eri salmonella- ja kampylobakteereille, jotka aiheuttavat vakavia ruokamyrkytyksiä ihmisille. Vuonna 2006 kananmunat ja kananmunatuotteet aiheuttivat $17.8 \%$ kaikista yksittäin raportoiduista epidemioista $(\mathrm{N}=3737)$. Yleisin taudin aiheuttaja kananmunissa ja kananmunatuotteissa on salmonella, http://www.efsa.europa.eu/cs/BlobServer/DocumentSet/Zoon_report_2006_en,0.pdf?ssbinary=true.

Kananmunalla on kuitenkin monta puolustuskeinoa vaarallisia taudinaiheuttajia vastaan. Ehjän kananmunan kuori ja siinä olevat valkuaisaineet ja kutikulakalvo estävät tehokkaasti taudinaiheuttajien pääsyn kananmunan sisään. Kananmunan valkuainen sisältää myös runsaasti taudinaiheuttajien kasvua ehkäiseviä ainesosia.

Toistaiseksi jalostajien käyttämät munankuorenlaadun mittausmenetelmät eivät ole laajaalaisesti ja kattavasti kuvanneet kananmunan kestävyyttä taudinaiheuttajia vastaan. SABRE työpaketissa pyritään yhdistämään uudet mittaustekniikat ja tietämys kananmunan kuoren hienorakenteesta. Samalla haetaan geenejä jotka vaikuttavat kuorenlaatuun molemmilla tavoilla. Näin pyritään tuottamaan jalostajille uusia työkaluja kuorenkestävyyden jalostamiseksi.

MTT:n lisäksi hankkeessa on mukana Institute National de la Recherche Agronomique, eli INRA Ranskasta, Roslin instituutti ja Glasgowin yliopisto Isosta-Britanniasta, ja Lohmann Tierzucht Saksasta. INRA:n osuus on tutkia eläimistä mitkä geenit ilmenevät kanan munanjohtimessa silloin kun munankuori rakentuu. Näin pyritään suoraan saamaan selville ne geenit joiden vaihtelu voi vaikuttaa munankuoren laatuun. Roslin instituutti keskittyy tietojen analysointiin ja tietojen hyväksi käyttöön valintalinjoissa. Roslin instituutin vastuuhenkilö erikoistutkija Ian Dunn toimii myös koko työpaketin koordinaattorina. Lohmann Tierzucht antaa materiaalia kartoitukseen ja uusien valintamenetelmien testaamiseen käytännön jalostuslinjoissa. Glasgowin yliopistossa kehitetään uusia kuorenkestävyyden mittausmenetelmiä. Samalla tutkitaan laboratoriokokeilla bakteerien kulkeutumista kuoren läpi.

\section{Aineisto ja menetelmät}

SABRE-hankkeessa tutkimuspopulaatio koostuu Lohmann Tierzucht jalostusyhtiön kahden eri ruskean linjan risteytyksestä. Noin 2000 kanasta koostuva tutkimussukupolvi oli koko tuotantokauden (elinviikot 18 - 60) tuotannontarkkailussa. Munan laatua tutkittiin Canadian Egg Shell Tester laitteella, jolla saadaan selville munankuoren jousto ja kesto, katso Taulukko 1. Kuoren paino mitattiin kerran elinviikolla 42. Kaikki mittaukset ovat kolmesta perättäisestä munasta tutkimusviikon aikana. Mittaustulokset korjattiin haudontaerän ja häkkipaikan suhteen.

Taulukko1. Mitatut ominaisuudet F2 populaatiossa, lyhenne, keskiarvo, SD, mitattu eläinmäärä, min, max ja variaatio kerroin

\begin{tabular}{llllllll} 
Ominaisuus & \multicolumn{2}{l}{ Lyhenne keskiarvo } & SD & F2 (n)min & $\max$ & CV \\
\hline Kuorenpaino 42 vk, gr & SW & 6.9 & 0.7 & 664 & 4.1 & 9.3 & 10 \\
Kuorenkesto 35 vk, kp & BF35 & 4.1 & 0.5 & 552 & 2.3 & 5.6 & 13 \\
Kuorenkesto 40 vk, kp & BF40 & 4.1 & 0.5 & 634 & 2.2 & 5.4 & 12 \\
Kuorenkesto 50 vk, kp & BF50 & 4.0 & 0.6 & 557 & 2.0 & 5.9 & 16 \\
Kuorenkesto 70 vk kp & BF70 & 3.6 & 0.7 & 600 & 1.1 & 5.6 & 19 \\
Jousto 35, 40, 50 vk 1/100mm & DE & 0.8 & 0.09 & 643 & 0.6 & 1.3 & 12 \\
Jousto 35 vk 1/100 mm & DE35 & 0.8 & 0.1 & 552 & 0.5 & 1.3 & 14 \\
Jousto 40 vk 1/100 mm & DE40 & 0.8 & 0.1 & 633 & 0.5 & 1.4 & 13 \\
Jousto 50 vk 1/100 mm & DE50 & 0.8 & 0.1 & 576 & 0.4 & 1.3 & 18
\end{tabular}


Vuoden 2007 loppuun mennessä tehtiin alustava kuorenlaatu ominaisuuksiin vaikuttavien kromosomialueiden kartoitus tutkimuspopulaation 668 eläimestä. Kaikista tutkimussukupolven eläimistä ja niiden vanhemmista ja isovanhemmista otettiin verinäyte, josta eristettiin DNA. DNA- merkkeinä käytettiin selkeästi tunnistettavia DNA-jaksoja, joiden paikka kromosomissa on tarkalleen jo määritetty. Näillä merkeillä ei itse ole vaikutusta tutkittavaan ominaisuuteen. Mitä lähempänä tiettyä geenimerkkiä ominaisuuteen vaikuttava geeni sijaitsee, sitä useammin geenimerkki ja geeni periytyvät yhdessä. Tätä tietoa käytetään hyväksi kun tilastotieteen menetelmillä analysoidaan minkä geenimerkin läheisyydessä tutkittavaan ominaisuuteen vaikuttava geeni sijaitsee. Tutkimus käsitti 160 DNAmerkkiä 26 kromosomissa. Tutkimuksessa testattiin erilaisia tilastollisia analyysimalleja sekä geenien yhdysvaikutuksia kuoren laatuominaisuuksiin yhteistyössä Roslin Instituutin kanssa.

\section{Tulokset ja tulosten tarkastelu}

Kanan genomista löytyi 12 genomitason ja 13 kromosomitason kuoren laatuun vaikuttavaa kromosomialueita, joista lupaavimmat valittiin jatkotutkimuksiin (Kuva1). Kuoren kestävyyteen ja joustoon sekä alku- että loppumunintakaudella vaikuttavia alueita löytyi kromosomeista 2, 3, 6, 14, ja Z. Ainoa ominaisuus jolle ei löytynyt tilastollisesti merkitsevää kromosomialuetta, oli kuorenkesto viikolla70. Kromosomissa $\mathrm{Z}$ on samalla kartoitusalueella vaikutus sekä kuorenkestoon että joustoon eri mittausajankohtana. Jatkokartoituksessa keskitytään näiden alueiden tarkempaan analysointiin koko 2000 eläimen populaatiossa käyttäen lähekkäin sijaitsevia DNA-merkkejä. MTT:ssä keskitytään kromosomeissa 14 ja Z oleviin alueisiin. Kuoren laatuun vaikuttavia kromosomialueita on raportoitu hyvin vähän. Review artikkelissa Abasth ym 2006, jossa yhdistettiin 50 eri julkaisun tulokset, löytyy kuorenpainoon, kananmunan ominaispainoon, kuorenpaksuuteen vaikuttavia alueita. Alueet eivät ole samoja kuin tässä tutkimuksessa löydetyt. Ainoastaan kromosomi 12:ssa sekä tässä tutkimuksessa että Abasth ym 2009 ovat löytäneet alueen joka vaikuttaa kuorenlaatuun.

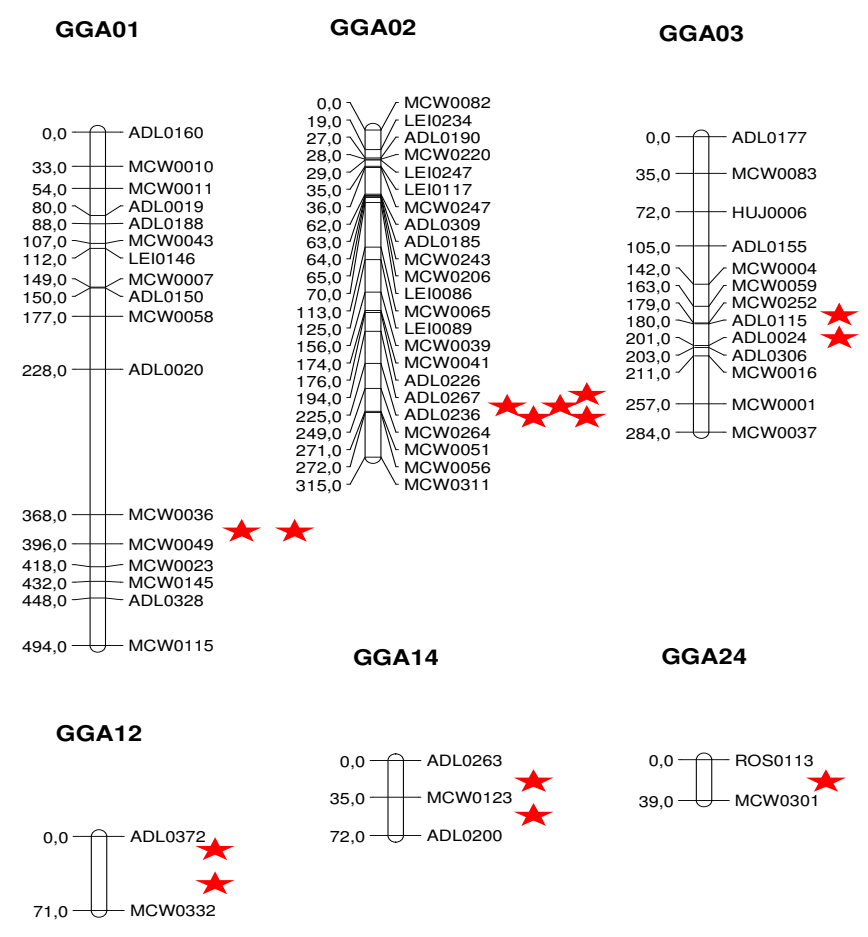

$$
\text { GGA06 }
$$

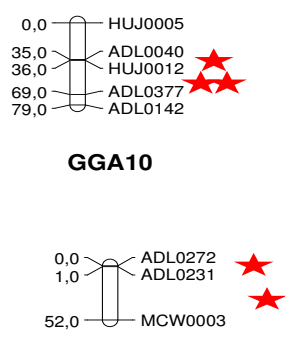

GGAOZ

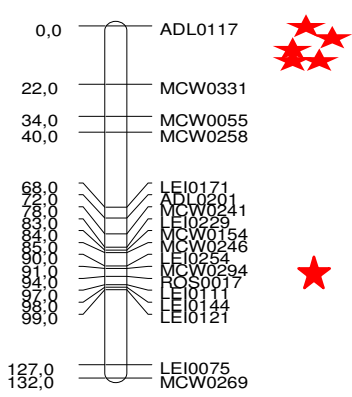

Kuva 1.

Kuvassa esitetty ne kanan kromosomit (geenimerkki, ja paikka cM) joissa löytyi kuorenlaatuun vaikuttavia alueita. Jokainen punainen tähti kuvaa löydettyä aluetta yhdelle ominaisuudelle. 


\section{Johtopäätökset}

Kuorenkestävyyden parantamiseksi kaikki hankkeesta saatu uusi tieto yhdistetään. INRA:n tietoa niistä geeneistä jotka ilmenevät kuoren muodostusvaiheessa verrataan löydettyjen kromosomialueiden vaikutuksiin kuoren laatuun. Jos esimerkiksi kuoren painoon vaikuttavalla kromosomialueella sijaitsee geeni jonka tiedetään liittyvän kalsiumaineenvaihduntaan, aletaan etsiä tästä geenistä sen toimintaan vaikuttavia muutoksia.

Jos sellaisia muutoksia löytyy, työ jatkuu näiden löytyneiden geenimuutosten vaikutusten testaamisella käytännön jalostuslinjoissa.

\section{Kirjallisuus}

Abasht, B., Dekkers, J.C.M, Lamont, S.J. 2006. Review of Quantitative Trait Loci Identified in the Chicken. Poultry Science 85:2079-2096.

Abasht B, Sandford E, Arango J, Settar P, Fulton JE, O'Sullivan NP, Hassen A, Habier D, Fernando RL, Dekkers JC, Lamont SJ. 2009 Extent and consistency of linkage disequilibrium and identification of DNA markers for production and egg quality traits in commercial layer chicken populations.BMC Genomics. Jul 14;10 Suppl $2: \mathrm{S} 2$.

http://www.efsa.europa.eu/cs/BlobServer/DocumentSet/Zoon_report_2006_en,0.pdf?ssbinary=true. 